\title{
II. AFRİKALI ÖĞRENCİLER ULUSLARARASI SEMPOZYUMU 12 ARALIK 2018/ANKARA
}

3 Aralık 2008'de kurulan Ankara Üniversitesi Afrika Çalışmaları Araştırma ve Uygulama Merkezi (AÇAUM), Türkiye'de bir üniversiteye bağlı olarak açılan ilk Afrika çalışmaları merkezidir. AÇAUM'un amacı, Türkiye'de Afrika kıtasını tanıtmak, Afrika'nın tarihine, coğrafyasına, kültürüne ve güncel sorunlarına dikkat çekmek ve Afrika ülkelerinde de Türkiye'yi tanıtmak ve bilinir kılmaktır. Bu çerçevede bir takım akademik, kültürel ve tarihi etkinliğe ev sahipliği yapan AÇAUM, Afrikalı Yüksek Öğrenim öğrencilerinin katılımı ile ilk uluslararası sempozyumunu 26 Mart 2015 tarihinde gerçekleştirmişti. Aynı sempozyumun ikincisi 12 Aralık 2018 tarihinde, Ankara Üniversitesi ilahiyat Fakültesinde gerçekleştirdi.

12 Aralık Çarşamba günü saat 14:00 da başlayan sempozyuma, Ankara Üniversitesi Rektör Yardımcısı Prof. Dr. Sibel Ayşı Özkan, AÇAUM Müdürü Prof. Dr. Nahide Bozkurt, Mdr. Yrd. Prof Dr. Ahmet Nedim Serinsu, illahiyat Fakültesi Dekanı Prof. Dr. İsmail Hakkı Ünal, TiKA yöneticileri, Öğretim üyeleri ve öğrenciler katıldı.

Prof. Dr. Sibel Ayşı Özkan, açııı̧ konuşmasında Türkiye'nin din eğitimi ve öğretiminde sahip olduğu müktesebata dikkat çekerek, AÜ ilahiyat Fakültesi'nin misyonuna vurgu yapt. Sağlıklı bir din eğitim ve öğretiminin önemine işaret eden Özkan, ülkemizin içinden geçtiği son yıllardaki en önemli problemlerin 
sağlıksız dini bilgilenmeden kaynaklandığını ifade etti. Daha sonra söz alan AÇAUM Müdürü Prof. Dr. Nahide Bozkurt ise, AÇAUM'un tarihçesi, misyonu ve vizyonu, gerçekleştirdiği etkinlikler ve ülkemizdeki önemini vurguladı. Bu manda, ikincisi düzenlenen Afrikalı Öğrenciler Uluslararası Sempozyumunun temasının Afrika ülkelerindeki Din Eğitimi ve Öğretimi olarak belirlendiğini ifade etti. AÜ İlahiyat Fakültesi dekanı Prof. Dr. İsmail Hakkı Ünal da, İlahiyat Fakültesinin ülkemiz akademisine yaptığı katkılara dikkat çekti. Aynı zamanda fakülte öğretim üyelerinin Üniversitenin etkinliklerine sağladığı katkılardan söz etti.

Açılış konuşmalarının akabinde, Ilahiyat Fakültesi öğretim elemanı Dr. Şahin Kızılabdullah tarafindan, “Afro-Amerikalıların Amerika'daki Dini Tarihi ve Durumu” başlıklı açılış tebliği sunuldu. Kızılabdullah, Afro-Amerikalıların ABD’nin tarihindeki önemine işaret ederek, tarihten günümüze ülkenin en hassas konularının başında Afro-Amerikalıların yer aldığını ifade etti. Afrika'nın dini durumu ile ilgili bilgier veren konuşmacı, Yerel Afrika Dinleri, Hıristiyanlık ve İslamiyet'in Afrikada yaylış sürecini anlatt. Köle ticaretinin başlaması ile Amerika'ya gerçekleşen göçler ve göç ettirilenlerin etnik ve dini yapıları hakkında ayrıntılı bilgiler verdi. 18.yy'dan itibaren Afro-Amerikalıların Hıristiyanlaştırılmaya başladığını belirten Kızılabdullah, ilk göçlerde yaklaşık \%30 civarında Afro-Amerikalının Müslüman iken şuan bu oranın \%1-2 seviyelerine indiğine işaret etti. AfroAmerikalılar tarafindan kurulan "Black Church" olarak isimlendirilen Hıristiyan geleneği hakkında bilgiler veren konuşmacı, bu geleneği diğerlerinden ayıran özelliklerine dikkat çekti. İkinci olarak Afro-Amerikalı Müslümanların durumuna değinen Kızılabdullah, İslam Milleti "Nation of Islam” grubu da dahil olmak üzere, Müslüman Afrikalıların Amerika'daki tarihi hakkında dinleyicileri aydınlatt. Kızılabdullah son olarak, Afro-Amerikalıların tarihinde önemli bir süreç olan Sivil Haklar Hareketi, bu hareketin lideri Dr. King ve sivil hak mücadeleleri esnasında meydana gelen önemli olayları izah etti.

Sempozyumun Afrikalı öğrenciler tarafindan gerçekleştirilen sunumlarına Aden JARSO, Faduma Mohammed ABDULLAHI, Mustafa ACAR, Sahibe MANDE, Emine TAYYAR-Furkan DEMIR birer tebliğ ile katıldı. Sakarya Üniversitesi Sosyal Bilimler Enstitüsü Doktora öğrencisi olan Aden JARSO, Kenya örneğine dair bir sunum gerçekleştirdi. Kenya'nın dini yapısı hakkında kısa bilgiler verdikten sonra Jarso, bu toplulukların ülke eğitim sistemindeki durumuna değindi. Nüfus itibariyle Hıristiyan, Müslüman ve Hindu gruplarının ülke yönetimi tarafindan tanınan gruplar olduğuna dikkat çekti. Hırsitiyan nüfusun yoğunluğu ve Kenya'nın tarihi geçmişi itibariyle Hıristiyanlığın ülkedeki etkisine dikkat çeken konuşmacı, birçok okulun Hıristiyanlar tarafindan idare edildiğine değindi. Jarso, devlet okullarının yanı sıra bu dini grupların kendilerine ait özel eğitim kurumlarına da sahip olduğu bilgisini paylaşt.

Ankara Üniversitesi, Sosyal Bilimler Enstitüsü, yüksek lisans öğrencisi Fa- 
duma Mohammed ABDULLAHI, "Somali'de Din Eğitimi ve Öğretimi" başlıklı tebliğinin girişinde, 14 milyon nüfuslu "Afrika Boynuzu" lakaplı Somali hakkında genel bilgiler sundu. Ülkesinin tanıtımından sonra Abdullahi, \%99 Müslüman olan Somali'yi diğer Afrika ülkelerinden ayıran özelliklerine değindi ve genel eğitim-öğretim sürecinin başlamasından önce, geleneksel yöntemlerle gerçekleştirilen Kuran öğretimi merkezli din eğitimi ve hafizlık çalışmaları hakkında bilgiler verdi. Konuşmacı, Arapça, Kuran ve temel dini bilgiler eğitiminin yapıldığı bu süreç tüm Somalilliler için aynı zamanda eğitim öğretim faaliyetlerinin de bir başlangıcı olarak kabul edildiğini dile getirdi. Abdullahi, bu eğitimin gönüllü hocalar tarafindan ve ailelerin hediyeleri(bağışları) ile gerçekleştirildiğini belirtti. Son olarak konuşmacı, illkokul eğitmi olarak değerlendirilen bu 2-3 yıllık sürecin akabinde, örgün eğitim ortaokul düzeyinde başladığını ve matematik, tarih gibi derslerin okutulduğunu, dini ilimlerde intisaslaşmak isteyenlerin ise, klasik dini ilimlerin okutulduğu medreselerde Arapça, Tefsir, Hadis, İslam Hukuku vb dersler okuyarak bilgilerini artrabildiğini ifade etti.

Üçüncü konuşmacı olarak Mustafa Acar, Etiopya(Habeşistan) din eğitimi ve öğretimi hakkında bir tebliğ sundu. Etiopya'nın tarihi sürecine ve Osmanlı ile olan derin ilişkilerine dikkat çeken konuşmacı, Etiopya'nın İslam ile tanışmasına vurgu yapt. Medine'den önce İslam ile tanışan bölgenin, diğer Afrika ülkelerinin aksine sömürge haline gelmemesinden dolayı, köklü bir dini ve kültürel mirasa sahip olduğuna dikkat çekti. Acar, 4 milyonunu kızların oluşturduğu 8 milyon çocuğun maddi imkânsızlıklar neticesinde eğitim öğretim haklarından mahrum kaldığı gerçeğini paylaşt. Ülkenin zorunlu bir eğitim sisteminin olmadığına dikkat çeken konuşmacı, devlet okullarında din eğitimi verilmediğini bu eksikliğin özel vakıflar ve kuruluşlar eliyle yürütüldüğünü dile getirdi. Misyonerlik faaliyetleri çerçevesinde Hıristiyan okullarının yaygınlığına işaret eden Acar, Müslümanların ise medreseler, cami halkaları ve sufi tekkeleri eliyle eğitim öğretimi gerçekleştirdiğine dikkat çekti. Konuşmacı, İslam İşleri Yüksek Konseyi, Müslümanların Maslahatını Koruma Cemiyeti, Hayır kurumları çatısı altında yetimlere, muhtaçlara barınma imkânı yanında dini eğitim içerikli aktiviteler, Camilerdeki ilim halkaları, Ortaokul ve lise düzeyinde son on yılda açılan okullar, Selefi Medreseler, Ahbaş Medreseleri ve Sufi Medresleri'nin bu eğitim faaliyetleri gerçekleştirdiğini belirtti.

Dördüncü konuşmacı olan Ankara Üniversitesi Sosyal Bilimler Enstitüsü Doktora öğrencisi Sahibe Mande, Burkino Faso'daki din eğitim-öğretimini anlatt. Mande, "Güvenilir İnsanlar Ülkesi” anlamına gelen Burkino Faso'nun uzun yıllar Fransız sömürgesi olarak kaldığını ve 20.yy'ın ortalarında bağımsızlığını kazandığını belirtti. 20 milyona yaklaşan nüfusunun birçok etnik kimlikten oluştuğuna dikkat çeken konuşmacı, bu nüfusun \%75'nin Müslüman \%23 kadarının ise Hıristiyanlardan meydana geldiğini ifade etmiştir. Oranının az olmasına rağ- 
men Katolik kilisesi başta olmak üzere, Hıristiyan grupların eğiti-öğretim faaliyetlerinde etkin rol oynadığı belirtilmiştir. Mande, ülkede 6 yıl ilkokul, 3 yıl ortaokul ve 3 yıl da lise olmak üzere 12 yıllık bir eğitim sürecinin olduğunu belirtmiştir. Tebliğci, din eğitimi açısından ise geleneksel ve modern medreseler olmak üzere iki tip eğitim-öğretim kurumunun varlığına dikkat çekmiş, Arapça, Kuran, Tefsir, Hadis, Fıkıh gibi temel İslami ilimlerin bu okullarda okutulduğunu belirtmiştir. Mande, resmi dilin Fransızca olması nedeniyle modern medreselerde Fransızcanın da öğretildiğine dikkat çekmiştir. Konuşmacı, İslam eğitiminin karşılaştığı sorunları belirterek sunumunu noktalamıştır.

Son konuşmacılar olarak, Emine Tayyar ve Furkan Demir isimli Ankara Üniversitesi İlahiyat Fakültesi öğrencileri "Türkiye'de Ders Kitaplarında Afrika” adlı tebliğlerini sunmuşlardır. Demir, yaptıkları incelemenin yöntemi hakkında bilgiler vermiş ve sözü Tayyar'a bırakmıştır. Tayyar da lise ders kitaplarından 9-10-11 ve 12 sınıf Tarih kitapları içerisinde Afrika ile ilgili bilgilere yer verilen üniteleri ve konu başlıklarını dinleyicilerle paylaşmıştır. İki konuşmacı da bu araştırmanın neticesinde, ders kitaplarında Afrika'ya, siyasi tarih açısından yer verildiğini, Türklerin ve İslam'ın Afrika'daki varlığı, Mısır ve Helen uygarlıklarının Afrika ile ilişkileri, Osmanlı dönemi ve Afrika bağlantısı ile Avrupa ülkelerinin sömürgecilik sürecinde Afrika'daki faaliyetleri başlıklarının ön plana çıktı̆ına dikkat çekmişlerdir.

Sunumların sonunda AÇAUM Mdr. Yrd. Prof. Dr. Ahmet Nedim Serinsu, sempozyum hakkında bir değerlendirme yapmıştır. Serinsu, birçok uygarlığa ev sahipliği yapan Afrika'nın nasıl "Kara Kıta” haline getirildiğine dikkat çekmiş ve Türkiye Cumhuriyeti'nin Orta Asya'dan Afrika'ya dünyanın birçok bölgesine götürdüğü hizmetlerden söz etmiştir. Müzakereci, tüm sunumları başarılı bulduğunu belirterek bunun birer başlangıç olduğunu dile getirmiştir. Serinsu, Afrika'daki din eğitim ve öğretiminde kullanılan yöntemlere ve metot eksikliklerine işaret ederek, bilimsel bilgiye duyulan ihtiyaca vurgu yapmıştır. Türkiye'de yetişmekte olan Afrikalı öğrencilerin ise hem kendileri hem de ülkeleri açısından büyük birer şans olduğuna dikkat çeken konuşmacı, bu öğrencilerin gelecekte ülkelerinde yaşayabilecekleri istihdam sorununun aşılması ile ülkelerinin din eğitim ve öğretimine büyük katkılar sunacağını belirtmiştir. Katılımcılara teşekkür belgelerinin takdim edilmesi ile sempozyum tamamlanmıştır.

\section{Notlar}

$\left(^{*}\right) \quad$ Dr., Ankara Üniversitesi Illahiyat Fakültesi. E-posta: sahinkizilabdullah@gmail.com 